\author{
RAFAє KosZeK \\ Uniwersytet Pedagogiczny w Krakowie, Polska \\ Pedagogical University of Cracow, Poland
}

\title{
Przejęcia europejskich firm jako przykłady chińskich inwestycii zagranicznych
}

\section{Acquisitions of European Companies as Examples of Chinese Foreign Investment}

\begin{abstract}
Streszczenie: W ostatnich latach obserwujemy coraz bardziej intensywną ekspansję kapitałową przedsiębiorstw pochodzących z Chińskiej Republiki Ludowej. Przejawem tego procesu są akwizycje europejskich przedsiębiorstw, których wartość i liczba stale wzrasta. Głównym celem chińskich inwestycji w Europie jest uzyskanie dostępu do technologii produkcji, które są w posiadaniu zaawansowanych firm Starego Kontynentu. Jest to konieczne w związku z reformami prowadzonymi obecnie przez władze chińskie. Ważnym motywem podejmowanych przejęć jest również chęć pozyskania renomowanych marek, $\mathrm{w}$ celu poprawy wizerunku wytwarzanych w Chinach produktów. Wraz ze wzrostem wartości i liczby przejęć europejskich podmiotów gospodarczych można zaobserwować dywersyfikację sektorową prowadzonych działań. Może to być oznaką pozytywnego trendu i wskazywać na duży potencjał chińskich inwestorów. Pomimo tego że przedsiębiorstwa pochodzące z Państwa Środka są nowymi graczami na europejskim rynku inwestycji zagranicznych, dla wielu pogrążonych w kryzysie firm z krajów zachodnich są ważnym źródłem kapitału niezbędnego do dalszego funkcjonowania, a w przyszłości ich znaczenie może jeszcze wzrosnąć.
\end{abstract}

\begin{abstract}
In recent years we have observed a more and more intensive capital expansion of Chinese companies. A manifestation of this process are the acquisitions of European companies whose value and number is constantly growing. The main objective of Chinese investment in Europe is gaining access to production technology that is in the possession of advanced companies. This is necessary in connection with the reforms currently undertaken by the Chinese authorities. An important motive of acquisitions is also the desire of acquiring well-known brands, in order to improve the image of the products manufactured in China. Together with the increase of the value and number of acquisitions of European enterprises, there is a visible diversification of sectoral activities of the acquired businesses. This may be a sign of a positive trend and indicate a high potential of Chinese investors. Despite the fact that companies from the Middle Kingdom are new players on the European foreign investment market, for many crisis-ridden companies from western countries they are an important source of capital necessary for further operation.
\end{abstract}

Słowa kluczowe: Chiny; Europa; inwestycje; przejęcia; przepływ kapitału Keywords: acquisitions; capital flow; China; Europe; investment

Otrzymano: 31 grudnia 2016

Received: 31 December 2016

Zaakceptowano: 14 sierpnia 2017

Accepted: 14 August 2017 


\section{Sugerowana cytacja / Suggested citation:}

Koszek, R. (2017). Przejęcia europejskich firm jako przykłady chińskich inwestycji zagranicznych. Prace Komisji Geografii Przemysłu Polskiego Towarzystwa Geograficznego, 31(4), 133-147. https://doi. org/10.24917/20801653.314.9

\section{WSTĘP}

Współczesne przemiany prowadzą do ciągłego tworzenia nowych powiązań międzynarodowych. Wielość zachodzących codziennie procesów oraz podmiotów biorących w nich udział, zmienność uwarunkowań, przenikanie się poszczególnych elementów życia społecznego, gospodarczego i politycznego, jest - pomimo niezwykle rozwiniętego systemu informacji - trudna do uporządkowania, prawidłowej interpretacji i tworzenia uogólnionego obrazu rzeczywistości. Jednym z procesów kształtujących ów trudno poznawalny ład są międzynarodowe przepływy kapitału pieniężnego. Niezliczona liczba transakcji dokonująca się na giełdach papierów wartościowych, za pomocą różnego rodzaju instytucji i podmiotów pośredniczących oraz w bezpośrednich transakcjach zainteresowanych stron, tworzy rozmaite układy, sieci powiązań.

Jednym z typów międzynarodowych przepływów pieniężnych są inwestycje zagraniczne, czyli przemieszczanie się przez granice państw środków finansowych. Coraz większa swoboda przepływu kapitału pieniężnego w skali globalnej nie powinna jednak prowadzić do mylnego wyobrażenia o globalnej wiosce, w której granice, systemy prawne, bariery czy ułatwienia instytucjonalne nie mają znaczenia w dokonujących się transakcjach. Takie wyobrażenia nie mają odzwierciedlenia w rzeczywistości i możemy obserwować, że to szeroko pojęte interesy państwowe, narodowe odgrywają jedną z kluczowych ról w relacjach ekonomicznych.

Wyróżniamy dwa główne rodzaje inwestycji zagranicznych. Są nimi inwestycje portfelowe i inwestycje bezpośrednie. Pierwsze są z założenia mniej znaczące i równocześnie zwracają mniejszą uwagę, ponieważ polegają na wykupieniu niewielkiej części udziałów podmiotu będącego celem transakcji1. Bardziej zauważalne są inwestycje bezpośrednie, w których nabywane są znaczące udziały przedsiębiorstwa będącego biorcą inwestycji (typu brownfield) lub środki finansowe służą do utworzenia nowej jednostki, filii inwestora, w miejscu dotąd niezagospodarowanym (typ greenfield).

Niniejsza praca skupiać się będzie na wybranych przykładach pierwszego ze wspomnianych typów, a mianowicie na przejęciach istniejących już przedsiębiorstw. Pod uwagę będą brane jedynie te transakcje, w których dzięki napływowi kapitału inwestor uzyskał ponad połowę udziałów w przejmowanym podmiocie, co pozwala mu na decydowanie o dalszych działaniach firmy. Selekcja ta swoje uzasadnienie znajduje $\mathrm{w}$ fakcie, iż przejęcia przedsiębiorstw nie są jedynie formą lokaty nadwyżek kapitału pieniężnego, lecz są przeprowadzane w celu wykorzystania zasobów zgromadzonych $\mathrm{w}$ trakcie dotychczasowego funkcjonowania przejmowanego podmiotu gospodarczego.

Od kilku lat Chiny, dzięki zgromadzonym rezerwom walutowym i systematycznie rozwijanej polityce wychodzenia na zewnątrz (going out), stają się nowym, ważnym inwestorem w skali światowej. Państwo Środka tradycyjnie kojarzone było jako biorca inwestycji dostarczanych z bogatych krajów zachodnich. Uzyskiwano dzięki nim kapitał oraz technologię produkcji, niezbędne do rozwoju zacofanego kraju, jakim ChRL

\footnotetext{
${ }^{1}$ Powszechnie przyjmuje się zasadę uznawaną przez Międzynarodowy Fundusz Walutowy (IMF) i Organizację Współpracy i Rozwoju, że inwestycja portfelowa dotyczy nabycia udziałów przedsiębiorstwa nieprzekraczających 10\% kapitału spółki.
} 
była przed trzydziestoma laty. Jednocześnie zachodnie firmy mogły czerpać wysokie zyski dzięki dostępności olbrzymiej liczby taniej siły roboczej. Od kilku lat dotychczasowy model rozwoju powoli się wyczerpuje, co jest przyczyną reform prowadzonych przez władze chińskie. Zwiększanie zasobów nie może być sposobem na dalszy rozwój, konieczne jest zwiększenie efektywności zgromadzonego do tej pory kapitału. Jednym z elementów wprowadzanych zmian jest ożywienie działalności chińskich przedsiębiorstw za granicą.

W ostatnich dwóch-trzech latach coraz więcej mówi się o pozyskiwaniu znaczących europejskich przedsiębiorstw przez chińskie firmy. Problem ten, wielokrotnie poruszany w mediach, nie doczekał się do tej pory wyczerpującego opracowania, a w krajowych publikacjach jest rzadko podejmowany. Temat chińskich inwestycji w Europie jest często przedmiotem opracowań instytutów badawczych (m.in. Hanemannn, Huotari, 2016; Casaburi, 2016). Opracowania naukowe poruszają różnorodne aspekty tego procesu. Badane są motywacje, determinanty i cechy charakterystyczne napływu chińskiego kapitału do Europy (Dreger, Schüler-Zhou, Schüller, 2015; Szunomar, 2016). Podejmowane są również instytucjonalne i prawne czynniki relacji inwestycyjnych Chin z Unią Europejską (Clegg, Voss, 2016).

W niniejszej pracy podjęto próbę zbadania najbardziej znaczących przejęć europejskich firm przez podmioty mające swoje siedziby w Państwie Środka. Szczególną uwagę poświęcono uporządkowaniu informacji na temat wcześniej wspomnianych transakcji, przez możliwie najbardziej rzetelne wyszukanie danych, ich klasyfikację oraz interpretację. Przeprowadzenie postępowania badawczego w ten sposób wynika z faktu, iż głównym problemem w badaniu chińskich inwestycji zagranicznych jest brak wiarygodnych i aktualnych statystyk, zarówno tych dostarczanych przez stronę chińską, jak i europejską. Badania te oparto więc na pojedynczych transakcjach, możliwych do jak najpełniejszej weryfikacji. Ten sposób uznano za stosowny do osiągnięcia celów niniejszej pracy.

W związku z tym przyjęto, że najbardziej odpowiednim źródłem danych będzie lista największych chińskich inwestycji zagranicznych tworzona i udostępniana przez American Enterprise Institute (AEI, 2016, 31 grudnia). Zawiera ona spis przeprowadzonych transakcji, których wartość przekroczyła $100 \mathrm{mln}$ dol. Dla poszczególnych zdarzeń w bazie AEI podana jest przybliżona data, nazwa inwestora i podmiotu przejmowanego, wartość inwestycji oraz branża. Korzystając z tych informacji, podjęto próbę zidentyfikowania przejęć europejskich firm. W niniejszej pracy wyselekcjonowano te, w których chiński podmiot uzyskał większościowe udziały, co pozwala mu na kierowanie dalszą działalnością przedsiębiorstwa. Weryfikacja każdej transakcji umożliwiła określenie dokładnej nazwy przejmowanego przedsiębiorstwa i jego siedziby oraz przyporządkowanie do odpowiedniej sekcji i działu według Polskiej Klasyfikacji Działalności Gospodarczej, która jest zgodna ze statystyczną klasyfikacją działalności gospodarczej w Unii Europejskiej.

Głównymi źródłami informacji w wyszukiwaniu i porządkowaniu informacji były agencje dostarczające informacji gospodarczych, przede wszystkim Bloomberg i Reuters, często korzystano również ze stron internetowych spółek. W wynikach nie uwzględniono inwestycji od podstaw, nie brano również pod uwagę transakcji typu joint-venture czy zakupu nieruchomości. Zakres czasowy obejmował okres od 2006 roku do końca pierwszej połowy 2016 roku. Następnie zgromadzone dane poddano analizie, posługując się wykresami i rycinami. Szczegółowe informacje dotyczące opracowanych danych znalazły się w tab. 1 . 
Tab. 1. Największe przejęcia europejskich przedsiębiorstw przez chińskich inwestorów w latach 2006-2016

\begin{tabular}{|c|c|c|c|c|}
\hline Inwestor & $\begin{array}{c}\text { Podmiot } \\
\text { przejmowany }\end{array}$ & Siedziba & Sekcja & Dział \\
\hline ChemChina & Adisseo & $\begin{array}{l}\text { Antony, } \\
\text { Francja } \\
\end{array}$ & $\begin{array}{l}\text { Przetwórstwo } \\
\text { przemysłowe }\end{array}$ & $\begin{array}{l}\text { Produkcja chemikaliów } \\
\text { i wyrobów chemicznych }\end{array}$ \\
\hline $\begin{array}{l}\text { Sichuan } \\
\text { Changhong }\end{array}$ & \begin{tabular}{|l} 
Sterope \\
investments
\end{tabular} & $\begin{array}{l}\text { Amsterdam, } \\
\text { Holandia } \\
\end{array}$ & $\begin{array}{l}\text { Rynek } \\
\text { nieruchomości }\end{array}$ & Rynek nieruchomości \\
\hline ChemChina & Rhodia & Paryż, Francja & $\begin{array}{l}\text { Przetwórstwo } \\
\text { przemysłowe }\end{array}$ & $\begin{array}{l}\text { Produkcja chemikaliów } \\
\text { i wyrobów chemicznych }\end{array}$ \\
\hline $\begin{array}{l}\text { LinkGlobal } \\
\text { Logistics }\end{array}$ & Parchim Airport & $\begin{array}{l}\text { Parchim, } \\
\text { Niemcy }\end{array}$ & $\begin{array}{l}\text { Transport } \\
\text { i gospodarka } \\
\text { magazynowa }\end{array}$ & Transport lotniczy \\
\hline $\begin{array}{l}\text { China Ocean } \\
\text { Shipping }\end{array}$ & Burg Industries & $\begin{array}{l}\text { Pijnacker, } \\
\text { Holandia } \\
\end{array}$ & $\begin{array}{l}\text { Przetwórstwo } \\
\text { przemysłowe }\end{array}$ & $\begin{array}{l}\text { Produkcja pozostałego sprzętu } \\
\text { transportowego }\end{array}$ \\
\hline Zoomlion & $\begin{array}{l}\text { Compagnia Italiana } \\
\text { Forme Acciaio } \\
\end{array}$ & $\begin{array}{l}\text { Senago, } \\
\text { Włochy }\end{array}$ & $\begin{array}{l}\text { Przetwórstwo } \\
\text { przemysłowe }\end{array}$ & $\begin{array}{l}\text { Produkcja maszyn i urządzeń, } \\
\text { gdzie indziej niesklasyfikowana }\end{array}$ \\
\hline $\begin{array}{l}\text { China Oilfield } \\
\text { Services }\end{array}$ & Awilco Offshore & Oslo, Norwegi & $\begin{array}{l}\text { Górnictwo } \\
\text { i wydobywanie }\end{array}$ & $\begin{array}{l}\text { Górnictwo ropy naftowej i gazu } \\
\text { ziemnego }\end{array}$ \\
\hline Sinochem & Emerald Energy & $\begin{array}{l}\text { Londyn, } \\
\text { Wlk. Brytania } \\
\end{array}$ & $\begin{array}{l}\text { Górnictwo } \\
\text { i wydobywanie }\end{array}$ & $\begin{array}{l}\text { Górnictwo ropy naftowej i gazu } \\
\text { ziemnego }\end{array}$ \\
\hline Sinopec & Addax Petroleum & $\begin{array}{l}\text { Genewa, } \\
\text { Szwajcaria }\end{array}$ & $\begin{array}{l}\text { Górnictwo } \\
\text { i wydobywanie }\end{array}$ & $\begin{array}{l}\text { Górnictwo ropy naftowej i gazu } \\
\text { ziemnego }\end{array}$ \\
\hline $\begin{array}{l}\text { Wanhua } \\
\text { Industrial }\end{array}$ & BorsodChem & $\begin{array}{l}\text { Kazincbarcika, } \\
\text { Węgry }\end{array}$ & $\begin{array}{l}\text { Przetwórstwo } \\
\text { przemysłowe }\end{array}$ & $\begin{array}{l}\text { Produkcja chemikaliów } \\
\text { i wyrobów chemicznych }\end{array}$ \\
\hline Geely Auto & Volvo & $\begin{array}{l}\text { Göteborg, } \\
\text { Szwecja }\end{array}$ & $\begin{array}{l}\text { Przetwórstwo } \\
\text { przemysłowe }\end{array}$ & $\begin{array}{l}\text { Produkcja pojazdów } \\
\text { samochodowych, przyczep } \\
\text { i naczep, z wyłączeniem } \\
\text { motocykli } \\
\end{array}$ \\
\hline $\begin{array}{l}\text { Wolong } \\
\text { Holding }\end{array}$ & ATB Group & $\begin{array}{l}\text { Wiedeń, } \\
\text { Austria }\end{array}$ & $\begin{array}{l}\text { Przetwórstwo } \\
\text { przemysłowe }\end{array}$ & $\begin{array}{l}\text { Produkcja urządzeń } \\
\text { elektrycznych }\end{array}$ \\
\hline CITIC & $\begin{array}{l}\text { KSM Castings } \\
\text { Group GmbH }\end{array}$ & $\begin{array}{l}\text { Hildesheim, } \\
\text { Niemcy }\end{array}$ & $\begin{array}{l}\text { Przetwórstwo } \\
\text { przemysłowe }\end{array}$ & Produkcja metali \\
\hline Lenovo & Medion AG & Essen, Niemcy & $\begin{array}{l}\text { Handel hurtowy } \\
\text { i detaliczny }\end{array}$ & $\begin{array}{l}\text { Handel hurtowy, z wyłączeniem } \\
\text { handlu pojazdami } \\
\text { samochodowymi }\end{array}$ \\
\hline Ningbo Joyson & Preh GmbH & $\begin{array}{l}\text { Bad Neustadt } \\
\text { an der Saale, } \\
\text { Niemcy } \\
\end{array}$ & $\begin{array}{l}\text { Przetwórstwo } \\
\text { przemysłowe }\end{array}$ & $\begin{array}{l}\text { Produkcja komputerów, } \\
\text { wyrobów elektronicznych } \\
\text { i optycznych }\end{array}$ \\
\hline $\begin{array}{l}\text { Beijing } \\
\text { Hainachuan } \\
\text { Automotive } \\
\text { Parts Co., Ltd. }\end{array}$ & $\begin{array}{l}\text { Inalfa Roof } \\
\text { Systems Group B.V. }\end{array}$ & $\begin{array}{l}\text { Venray, } \\
\text { Holandia }\end{array}$ & $\begin{array}{l}\text { Przetwórstwo } \\
\text { przemysłowe }\end{array}$ & $\begin{array}{l}\text { Produkcja pojazdów } \\
\text { samochodowych, przyczep } \\
\text { i naczep, z wyłączeniem } \\
\text { motocykli }\end{array}$ \\
\hline $\begin{array}{l}\text { China National } \\
\text { Bluestar Co. } \\
\text { Ltd. }\end{array}$ & Elkem & Oslo, Norwegia & $\begin{array}{l}\text { Przetwórstwo } \\
\text { przemysłowe }\end{array}$ & $\begin{array}{l}\text { Produkcja chemikaliów } \\
\text { i wyrobów chemicznych }\end{array}$ \\
\hline Bright Foods & Weetabix Limited & $\begin{array}{l}\text { Burton } \\
\text { Latimer, } \\
\text { Wlk. Brytania } \\
\end{array}$ & $\begin{array}{l}\text { Przetwórstwo } \\
\text { przemysłowe }\end{array}$ & $\begin{array}{l}\text { Produkcja artykułów } \\
\text { spożywczych }\end{array}$ \\
\hline Hanergy & Solibro GmbH & $\begin{array}{l}\text { Bitterfeld- } \\
\text {-Wolfen, } \\
\text { Niemcy } \\
\end{array}$ & $\begin{array}{l}\text { Przetwórstwo } \\
\text { przemysłowe }\end{array}$ & $\begin{array}{l}\text { Produkcja komputerów, } \\
\text { wyrobów elektronicznych } \\
\text { i optycznych }\end{array}$ \\
\hline Sany Heavy & $\begin{array}{l}\text { Putzmeister } \\
\text { Holding GmbH }\end{array}$ & $\begin{array}{l}\text { Aichtal, } \\
\text { Niemcy }\end{array}$ & $\begin{array}{l}\text { Przetwórstwo } \\
\text { przemysłowe }\end{array}$ & $\begin{array}{l}\text { Produkcja maszyn i urządzeń, } \\
\text { gdzie indziej niesklasyfikowana }\end{array}$ \\
\hline
\end{tabular}




\begin{tabular}{|c|c|c|c|c|}
\hline Inwestor & $\begin{array}{c}\text { Podmiot } \\
\text { przejmowany }\end{array}$ & Siedziba & Sekcja & Dział \\
\hline $\begin{array}{l}\text { Xuzhou } \\
\text { Constr. } \\
\text { Machinery }\end{array}$ & Schwing GmbH & Herne, Niemcy & $\begin{array}{l}\text { Przetwórstwo } \\
\text { przemysłowe }\end{array}$ & $\begin{array}{l}\text { Produkcja maszyn i urządzeń, } \\
\text { gdzie indziej niesklasyfikowana }\end{array}$ \\
\hline $\begin{array}{l}\text { Weichai } \\
\text { Power Co. Ltd }\end{array}$ & Ferretti & Forli, Włochy & $\begin{array}{l}\text { Przetwórstwo } \\
\text { przemysłowe }\end{array}$ & $\begin{array}{l}\text { Produkcja pozostałego sprzętu } \\
\text { transportowego }\end{array}$ \\
\hline $\begin{array}{l}\text { Guangxi } \\
\text { Liugong } \\
\text { Machin. }\end{array}$ & Huta Stalowa Wola & $\begin{array}{l}\text { Stalowa Wola, } \\
\text { Polska }\end{array}$ & $\begin{array}{l}\text { Przetwórstwo } \\
\text { przemysłowe }\end{array}$ & $\begin{array}{l}\text { Produkcja maszyn i urządzeń, } \\
\text { gdzie indziej niesklasyfikowana }\end{array}$ \\
\hline Dalian Wanda & \begin{tabular}{|l} 
Sunseeker \\
International Ltd
\end{tabular} & $\begin{array}{l}\text { Poole, } \\
\text { Wlk. Brytania }\end{array}$ & $\begin{array}{l}\text { Przetwórstwo } \\
\text { przemysłowe }\end{array}$ & $\begin{array}{l}\text { Produkcja pozostałego sprzętu } \\
\text { transportowego }\end{array}$ \\
\hline Geely Auto & $\begin{array}{l}\text { Manganese Bronze } \\
\text { (London Taxi Corp. } \\
\text { Ltd) }\end{array}$ & $\begin{array}{l}\text { Coventry, } \\
\text { Wlk. Brytania }\end{array}$ & $\begin{array}{l}\text { Przetwórstwo } \\
\text { przemysłowe }\end{array}$ & $\begin{array}{l}\text { Produkcja pojazdów } \\
\text { samochodowych, przyczep } \\
\text { i naczep, z wyłączeniem } \\
\text { motocykli }\end{array}$ \\
\hline Sinoma & Hazemag \& EPR & $\begin{array}{l}\text { Dülmen, } \\
\text { Niemcy }\end{array}$ & $\begin{array}{l}\text { Przetwórstwo } \\
\text { przemysłowe }\end{array}$ & $\begin{array}{l}\text { Produkcja maszyn i urządzeń, } \\
\text { gdzie indziej niesklasyfikowana }\end{array}$ \\
\hline $\begin{array}{l}\text { Tri Ring Group } \\
\text { Corporation }\end{array}$ & $\begin{array}{l}\text { Fabryka Łożysk } \\
\text { Tocznych-Kraśnik }\end{array}$ & Kraśnik, Polska & $\begin{array}{l}\text { Przetwórstwo } \\
\text { przemysłowe }\end{array}$ & $\begin{array}{l}\text { Produkcja maszyn i urządzeń, } \\
\text { gdzie indziej niesklasyfikowana }\end{array}$ \\
\hline Anbang & Fidea NV & $\begin{array}{l}\text { Antwerpia, } \\
\text { Belgia }\end{array}$ & $\begin{array}{l}\text { Finanse } \\
\text { i ubezpieczenia }\end{array}$ & $\begin{array}{l}\text { Ubezpieczenia, reasekuracja } \\
\text { oraz fundusze emerytalne }\end{array}$ \\
\hline Anbang & $\begin{array}{l}\text { Delta Lloyd Bank } \\
\text { Belgium }\end{array}$ & $\begin{array}{l}\text { Bruksela, } \\
\text { Belgia }\end{array}$ & $\begin{array}{l}\text { Finanse } \\
\text { i ubezpieczenia }\end{array}$ & $\begin{array}{l}\text { Finansowa działalność, } \\
\text { z wyłączeniem funduszów } \\
\text { emerytalnych }\end{array}$ \\
\hline Geely Auto & $\begin{array}{l}\text { Emerald } \\
\text { Automotive Design } \\
\text { Ltd }\end{array}$ & $\begin{array}{l}\text { Brentwood, } \\
\text { Wlk. Brytania }\end{array}$ & $\begin{array}{l}\text { Przetwórstwo } \\
\text { przemysłowe }\end{array}$ & $\begin{array}{l}\text { Produkcja pojazdów } \\
\text { samochodowych, przyczep } \\
\text { i naczep, z wyłączeniem } \\
\text { motocykli }\end{array}$ \\
\hline ICBC & $\begin{array}{l}\text { Standard Bank } \\
\text { Limited, Londyn }\end{array}$ & $\begin{array}{l}\text { Londyn, } \\
\text { Wlk. Brytania }\end{array}$ & $\begin{array}{l}\text { Finanse } \\
\text { i ubezpieczenia }\end{array}$ & $\begin{array}{l}\text { Finansowa działalność, } \\
\text { z wyłączeniem funduszów } \\
\text { emerytalnych }\end{array}$ \\
\hline Legend & $\begin{array}{l}\text { PizzaExpress } \\
\text { Limited }\end{array}$ & $\begin{array}{l}\text { Londyn, } \\
\text { Wlk. Brytania }\end{array}$ & $\begin{array}{l}\text { Zakwaterowanie } \\
\text { i usługi } \\
\text { gastronomiczne }\end{array}$ & $\begin{array}{l}\text { Działalność usługowa związana } \\
\text { z wyżywieniem }\end{array}$ \\
\hline Sanpower & $\begin{array}{l}\text { House of Fraser } \\
\text { Limited }\end{array}$ & \begin{tabular}{|l} 
Londyn, \\
Wlk. Brytania \\
\end{tabular} & $\begin{array}{l}\text { Handel hurtowy } \\
\text { i detaliczny }\end{array}$ & Handel detaliczny \\
\hline Huaxin & $\begin{array}{l}\text { Alcatel-Lucent } \\
\text { Enterprise S.A. }\end{array}$ & $\begin{array}{l}\text { Colombes, } \\
\text { Francja }\end{array}$ & $\begin{array}{l}\text { Informacja } \\
\text { i komunikacja }\end{array}$ & Telekomunikacja \\
\hline $\begin{array}{l}\text { Jin Jiang } \\
\text { Hotels }\end{array}$ & Louvre Hotels SAS & Paryż, Francja & $\begin{array}{l}\text { Zakwaterowanie } \\
\text { i usługi } \\
\text { gastronomiczne }\end{array}$ & $\begin{array}{l}\text { Hotele i podobne obiekty } \\
\text { zakwaterowania }\end{array}$ \\
\hline AVIC & $\begin{array}{l}\text { Hilite Germany } \\
\text { GmbH }\end{array}$ & $\begin{array}{l}\text { Marktheiden- } \\
\text { feld, Niemcy }\end{array}$ & $\begin{array}{l}\text { Przetwórstwo } \\
\text { przemysłowe }\end{array}$ & $\begin{array}{l}\text { Produkcja maszyn i urządzeń, } \\
\text { gdzie indziej niesklasyfikowana }\end{array}$ \\
\hline Goodbaby & $\begin{array}{l}\text { Columbus Holding } \\
\text { GmbH }\end{array}$ & $\begin{array}{l}\text { Bayreuth, } \\
\text { Niemcy }\end{array}$ & $\begin{array}{l}\text { Przetwórstwo } \\
\text { przemysłowe }\end{array}$ & $\begin{array}{l}\text { Produkcja pozostałego sprzętu } \\
\text { transportowego }\end{array}$ \\
\hline COFCO & Nidera B.V. & $\begin{array}{l}\text { Rotterdam, } \\
\text { Holandia } \\
\end{array}$ & $\begin{array}{l}\text { Handel hurtowy } \\
\text { i detaliczny }\end{array}$ & Handel hurtowy \\
\hline ChemChina & REC Solar ASA & $\begin{array}{l}\text { Sandvika, } \\
\text { Norwegia }\end{array}$ & $\begin{array}{l}\text { Przetwórstwo } \\
\text { przemysłowe }\end{array}$ & $\begin{array}{l}\text { Produkcja komputerów, } \\
\text { wyrobów elektronicznych } \\
\text { i optycznych }\end{array}$ \\
\hline Fosun & $\begin{array}{l}\text { Espirito Santo Saude } \\
\text { (Luz Saúde, S.A) }\end{array}$ & $\begin{array}{l}\text { Lizbona, } \\
\text { Portugalia }\end{array}$ & $\begin{array}{l}\text { Opieka } \\
\text { zdrowotna }\end{array}$ & Opieka zdrowotna \\
\hline
\end{tabular}




\begin{tabular}{|c|c|c|c|c|}
\hline Inwestor & $\begin{array}{c}\text { Podmiot } \\
\text { przejmowany }\end{array}$ & Siedziba & Sekcja & Dział \\
\hline $\begin{array}{l}\text { Haitong } \\
\text { Securities }\end{array}$ & \begin{tabular}{|l|} 
Banco Espírito \\
Santo de Invest, S.A
\end{tabular} & $\begin{array}{l}\text { Lizbona, } \\
\text { Portugalia }\end{array}$ & $\begin{array}{l}\text { Finanse } \\
\text { i ubezpieczenia }\end{array}$ & $\begin{array}{l}\text { Finansowa działalność, } \\
\text { z wyłączeniem funduszów } \\
\text { emerytalnych }\end{array}$ \\
\hline $\begin{array}{l}\text { Hebei Iron and } \\
\text { Steel }\end{array}$ & \begin{tabular}{|l|} 
Duferco Intern. \\
Trading Holding SA \\
\end{tabular} & $\begin{array}{l}\text { Lugano, } \\
\text { Szwajcaria } \\
\end{array}$ & $\begin{array}{l}\text { Handel hurtowy } \\
\text { i detaliczny }\end{array}$ & Handel hurtowy \\
\hline AVIC & $\begin{array}{l}\text { AIM Aviation } \\
\text { Limited }\end{array}$ & $\begin{array}{l}\text { Bournemouth, } \\
\text { Wlk. Brytania }\end{array}$ & $\begin{array}{l}\text { Przetwórstwo } \\
\text { przemysłowe }\end{array}$ & $\begin{array}{l}\text { Produkcja pozostałego sprzętu } \\
\text { transportowego }\end{array}$ \\
\hline $\begin{array}{l}\text { C Banner } \\
\text { International }\end{array}$ & $\begin{array}{l}\text { The Hamleys Group } \\
\text { Ltd }\end{array}$ & $\begin{array}{l}\text { Londyn, } \\
\text { Wlk. Brytania } \\
\end{array}$ & $\begin{array}{l}\text { Handel hurtowy } \\
\text { i detaliczny }\end{array}$ & Handel detaliczny \\
\hline CSR & \begin{tabular}{|l|} 
Specialist Machine \\
Developments SMD \\
\end{tabular} & $\begin{array}{l}\text { Newcastle, } \\
\text { Wlk. Brytania } \\
\end{array}$ & $\begin{array}{l}\text { Przetwórstwo } \\
\text { przemysłowe }\end{array}$ & $\begin{array}{l}\text { Produkcja maszyn i urządzeń, } \\
\text { gdzie indziej niesklasyfikowana }\end{array}$ \\
\hline Ctrip & Travelfusion & $\begin{array}{l}\text { Londyn, } \\
\text { Wlk. Brytania }\end{array}$ & $\begin{array}{l}\text { Zakwaterowanie } \\
\text { i usługi } \\
\text { gastronomiczne }\end{array}$ & Zakwaterowanie \\
\hline NetDragon & $\begin{array}{l}\text { Promethean World } \\
\text { Plc } \\
\end{array}$ & $\begin{array}{l}\text { Blackburn, } \\
\text { Wlk. Brytania } \\
\end{array}$ & Edukacja & Edukacja \\
\hline Fosun & Club Med & Paryż, Francja & $\begin{array}{l}\text { Zakwaterowanie } \\
\text { i usługi } \\
\text { gastronomiczne }\end{array}$ & Zakwaterowanie \\
\hline $\begin{array}{l}\text { Anhui } \\
\text { Zhongding }\end{array}$ & Wegu Holding & Kassel, Niemcy & $\begin{array}{l}\text { Przetwórstwo } \\
\text { przemysłowe }\end{array}$ & \begin{tabular}{|l|} 
Produkcja pojazdów \\
samochodowych, przyczep \\
i naczep, z wyłączeniem \\
motocykli \\
\end{tabular} \\
\hline Fosun & $\begin{array}{l}\text { Hauck \& Aufhäuser } \\
\text { Privatbank. KGaA }\end{array}$ & $\begin{array}{l}\text { Frankfurt, } \\
\text { Niemcy }\end{array}$ & $\begin{array}{l}\text { Finanse } \\
\text { i ubezpieczenia }\end{array}$ & $\begin{array}{l}\text { Finansowa działalność, } \\
\text { z wyłączeniem funduszów } \\
\text { emerytalnych }\end{array}$ \\
\hline Ningbo Joyson & Quin GmbH & $\begin{array}{l}\text { Rutesheim, } \\
\text { Niemcy }\end{array}$ & $\begin{array}{l}\text { Przetwórstwo } \\
\text { przemysłowe }\end{array}$ & $\begin{array}{l}\text { Produkcja pojazdów } \\
\text { samochodowych, przyczep } \\
\text { i naczep, z wyłączeniem } \\
\text { motocykli } \\
\end{array}$ \\
\hline HNA & Avolon & $\begin{array}{l}\text { Dublin, } \\
\text { Irlandia Płd. }\end{array}$ & $\begin{array}{l}\text { Transport } \\
\text { i gospodarka } \\
\text { magazynowa } \\
\end{array}$ & Transport lotniczy \\
\hline $\begin{array}{l}\text { ChemChina } \\
\text { and SAFE }\end{array}$ & Pirelli & $\begin{array}{l}\text { Mediolan, } \\
\text { Włochy }\end{array}$ & $\begin{array}{l}\text { Przetwórstwo } \\
\text { przemysłowe }\end{array}$ & $\begin{array}{l}\text { Produkcja wyrobów z gumy } \\
\text { i tworzyw sztucznych }\end{array}$ \\
\hline Anbang & Vivat NV & \begin{tabular}{|l} 
Utrecht, \\
Holandia \\
\end{tabular} & $\begin{array}{l}\text { Finanse } \\
\text { i ubezpieczenia }\end{array}$ & $\begin{array}{l}\text { Pozostała działalność } \\
\text { wspomagająca usługi finansowe }\end{array}$ \\
\hline Bright Foods & $\begin{array}{l}\text { Miquel Alimentació } \\
\text { Grup, S.A.U. }\end{array}$ & $\begin{array}{l}\text { Vilamalla, } \\
\text { Hiszpania } \\
\end{array}$ & $\begin{array}{l}\text { Handel hurtowy } \\
\text { i detaliczny }\end{array}$ & Handel hurtowy \\
\hline $\begin{array}{l}\text { China } \\
\text { Minsheng } \\
\text { Investment }\end{array}$ & \begin{tabular}{|l|} 
Sirius International \\
Insurance Group \\
Ltd
\end{tabular} & $\begin{array}{l}\text { Sztokholm, } \\
\text { Szwecja }\end{array}$ & $\begin{array}{l}\text { Finanse } \\
\text { i ubezpieczenia }\end{array}$ & $\begin{array}{l}\text { Ubezpieczenia, reasekuracja } \\
\text { oraz fundusze emerytalne }\end{array}$ \\
\hline Dalian Wanda & $\begin{array}{l}\text { Infront Sports \& } \\
\text { Media }\end{array}$ & Zug, Szwajcaria & $\begin{array}{l}\text { Działalność } \\
\text { profesjonalna, } \\
\text { naukowa } \\
\text { i techniczna } \\
\end{array}$ & $\begin{array}{l}\text { Reklama, badanie rynku i opinii } \\
\text { publicznej }\end{array}$ \\
\hline HNA & $\begin{array}{l}\text { Swissport } \\
\text { International AG }\end{array}$ & $\begin{array}{l}\text { Opfikon, } \\
\text { Szwajcaria }\end{array}$ & \begin{tabular}{|l|} 
Transport \\
i gospodarka \\
magazynowa \\
\end{tabular} & $\begin{array}{l}\text { Magazynowanie i działalność } \\
\text { usługowa wspomagająca } \\
\text { transport }\end{array}$ \\
\hline Creat Group & $\begin{array}{l}\text { Bio Products } \\
\text { Laboratories } \\
\text { Limited }\end{array}$ & $\begin{array}{l}\text { Elstree, } \\
\text { Wlk. Brytania }\end{array}$ & $\begin{array}{l}\text { Działalność } \\
\text { profesjonalna, } \\
\text { naukowa } \\
\text { i techniczna } \\
\end{array}$ & $\begin{array}{l}\text { Badania naukowe i prace } \\
\text { rozwojowe }\end{array}$ \\
\hline
\end{tabular}




\begin{tabular}{|c|c|c|c|c|}
\hline Inwestor & $\begin{array}{c}\text { Podmiot } \\
\text { przejmowany }\end{array}$ & Siedziba & Sekcja & Dział \\
\hline Recon Group & $\begin{array}{l}\text { Aston Villa Football } \\
\text { Club Limited }\end{array}$ & $\begin{array}{l}\text { Birmingham, } \\
\text { Wlk. Brytania }\end{array}$ & $\begin{array}{l}\text { Kultura, } \\
\text { rozrywka } \\
\text { i rekreacja }\end{array}$ & $\begin{array}{l}\text { Działalność sportowa, } \\
\text { rozrywkowa i rekreacyjna }\end{array}$ \\
\hline $\begin{array}{l}\text { Shandong } \\
\text { Hongda }\end{array}$ & Jagex & \begin{tabular}{|l} 
Cambridge, \\
Wlk. Brytania \\
\end{tabular} & $\begin{array}{l}\text { Informacja } \\
\text { i komunikacja } \\
\end{array}$ & Działalność wydawnicza \\
\hline $\begin{array}{l}\text { Shanghai } \\
\text { Inesa }\end{array}$ & Havells & $\begin{array}{l}\text { Londyn, } \\
\text { Wlk. Brytania }\end{array}$ & $\begin{array}{l}\text { Przetwórstwo } \\
\text { przemysłowe }\end{array}$ & $\begin{array}{l}\text { Produkcja urządzeń } \\
\text { elektrycznych }\end{array}$ \\
\hline $\begin{array}{l}\text { China National } \\
\text { Silicon }\end{array}$ & Okmetic & $\begin{array}{l}\text { Vantaa, } \\
\text { Finlandia }\end{array}$ & $\begin{array}{l}\text { Przetwórstwo } \\
\text { przemysłowe }\end{array}$ & $\begin{array}{l}\text { Produkcja komputerów, } \\
\text { wyrobów elektronicznych } \\
\text { i optycznych }\end{array}$ \\
\hline Tencent & Supercell Oy & \begin{tabular}{|l} 
Helsinki, \\
Finlandia \\
\end{tabular} & \begin{tabular}{|l} 
Informacja \\
i komunikacja \\
\end{tabular} & Działalność wydawnicza \\
\hline $\begin{array}{l}\text { Shandong } \\
\text { Ruyi }\end{array}$ & SMCP S.A.S. & Paryż, Francja & $\begin{array}{l}\text { Handel hurt } \\
\text { i detal }\end{array}$ & Handel detaliczny \\
\hline $\begin{array}{l}\text { Beijing } \\
\text { Enterprises }\end{array}$ & $\begin{array}{l}\text { EEW Energy from } \\
\text { Waste GmbH }\end{array}$ & $\begin{array}{l}\text { Helmstedt, } \\
\text { Niemcy }\end{array}$ & $\begin{array}{l}\text { Wytwarzanie } \\
\text { i zaopatrywanie } \\
\text { w energię } \\
\text { elektryczną } \\
\end{array}$ & $\begin{array}{l}\text { Wytwarzanie i zaopatrywanie } \\
\text { w energię elektryczną }\end{array}$ \\
\hline ChemChina & KraussMaffei Group & $\begin{array}{l}\text { Monachium, } \\
\text { Niemcy }\end{array}$ & $\begin{array}{l}\text { Przetwórstwo } \\
\text { przemysłowe }\end{array}$ & $\begin{array}{l}\text { Produkcja maszyn i urządzeń, } \\
\text { gdzie indziej niesklasyfikowana }\end{array}$ \\
\hline Ningbo Joyson & $\begin{array}{l}\text { TechniSat Digital } \\
\text { GmbH }\end{array}$ & Daun, Niemcy & $\begin{array}{l}\text { Przetwórstwo } \\
\text { przemysłowe }\end{array}$ & $\begin{array}{l}\text { Produkcja komputerów, } \\
\text { wyrobów elektronicznych } \\
\text { i optycznych }\end{array}$ \\
\hline Three Gorges & WindMW GmbH & $\begin{array}{l}\text { Gadebusch, } \\
\text { Niemcy }\end{array}$ & $\begin{array}{l}\text { Wytwarzanie } \\
\text { i zaopatrywanie } \\
\text { w energię } \\
\text { elektryczną } \\
\end{array}$ & $\begin{array}{l}\text { Wytwarzanie i zaopatrywanie } \\
\text { w energię elektryczną }\end{array}$ \\
\hline $\begin{array}{l}\text { China Ocean } \\
\text { Shipping }\end{array}$ & Port of Piraeus & Pireus, Grecja & \begin{tabular}{|l|} 
Transport \\
i gospodarka \\
magazynowa \\
\end{tabular} & $\begin{array}{l}\text { Magazynowanie i działalność } \\
\text { usługowa wspomagająca } \\
\text { transport }\end{array}$ \\
\hline Agic Capital & Gimatic Srl & \begin{tabular}{|l} 
Roncadelle, \\
Włochy
\end{tabular} & $\begin{array}{l}\text { Przetwórstwo } \\
\text { przemysłowe }\end{array}$ & $\begin{array}{l}\text { Produkcja maszyn i urządzeń, } \\
\text { gdzie indziej niesklasyfikowana }\end{array}$ \\
\hline Suning & Inter Milan & $\begin{array}{l}\text { Mediolan, } \\
\text { Włochy }\end{array}$ & $\begin{array}{l}\text { Kultura, } \\
\text { rozrywka } \\
\text { i rekreacja } \\
\end{array}$ & $\begin{array}{l}\text { Działalność sportowa, } \\
\text { rozrywkowa i rekreacyjna }\end{array}$ \\
\hline $\begin{array}{l}\text { Shandong } \\
\text { Heavy }\end{array}$ & \begin{tabular}{|l|} 
DH Services \\
Luxembourg \\
Holding S.à.r.l \\
\end{tabular} & Luksemburg & \begin{tabular}{|l} 
Transport \\
i gospodarka \\
magazynowa \\
\end{tabular} & $\begin{array}{l}\text { Magazynowanie i działalność } \\
\text { usługowa wspomagająca } \\
\text { transport }\end{array}$ \\
\hline $\begin{array}{l}\text { Qihoo and } \\
\text { Beijing Kunlun } \\
\text { Technology } \\
\text { led } \\
\text { consortium }\end{array}$ & Opera Software AS & Oslo, Norwegia & $\begin{array}{l}\text { Informacja } \\
\text { i komunikacja }\end{array}$ & $\begin{array}{l}\text { Działalność związana } \\
\text { z oprogramowaniem } \\
\text { i doradztwem w zakresie } \\
\text { informatyki oraz działalność } \\
\text { powiązana }\end{array}$ \\
\hline Reignwood & $\begin{array}{l}\text { VOSS of Norway } \\
\text { ASA }\end{array}$ & Oslo, Norwegia & $\begin{array}{l}\text { Przetwórstwo } \\
\text { przemysłowe }\end{array}$ & Produkcja napojów \\
\hline Everbright & NOVAGO sp. z o.o. & Mława, Polska & $\begin{array}{l}\text { Gospodarowanie } \\
\text { ściekami } \\
\text { i odpadami }\end{array}$ & $\begin{array}{l}\text { Działalność związana ze } \\
\text { zbieraniem, przetwarzaniem } \\
\text { i unieszkodliwianiem odpadów }\end{array}$ \\
\hline
\end{tabular}

Źródło: opracowanie własne na podstawie danych AEI (2016, 31 grudnia) 


\section{GOSPODARKA CHRL - DOJRZEWAJĄCE MOCARSTWO W OKRESIE PRZEMIAN}

Od niespełna 40 lat obserwujemy stały, szybki rozwój chińskiej gospodarki. Wraz z rosnącym potencjałem ekonomicznym Państwo Środka coraz częściej uznawane jest za kraj, który w przyszłości może zastąpić Stany Zjednoczone jako światowego lidera, a obecnie jest już niewątpliwie potęgą regionalną. J. Sulmicki (2015) dostrzega w dokonujących się współcześnie procesach globalnych zjawisko przegięcia trendu milenijnego, czyli bardzo znaczącej zmiany, dokonującej się tak rzadko, że widoczna jest ona jedynie z perspektywy tysiąclecia. Zmiana taka dokonuje się przez dziesięciolecia, lecz jej skutki obserwujemy przez następne stulecia. Efektem nadchodzących przemian ma być nowy porządek, oparty na dominacji Chin jako globalnego mocarstwa.

Ogromne znaczenie temu procesowi nadaje fakt, iż mamy do czynienia z końcem porządku światowego opartego na dominacji krajów cywilizacji europejskiej na rzecz cywilizacji azjatyckiej. Po okresach supremacji Hiszpanii (XVI-XVII wieku), Francji (XVII-XVIII wieku), Wielkiej Brytanii i imperium brytyjskiego (od XIX wieku do końca drugiej wojny światowej) oraz Stanów Zjednoczonych (po II wojnie światowej), czyli po przechodzeniu dominacji globalnej w odstępach czasu zbliżonych do 100 lat (trend sekularny) w obrębie cywilizacji zachodniej, może przesunąć się ona w stronę cywilizacji azjatyckiej, reprezentowanej przez Chiny. Będzie to więc nie tylko zmiana kraju dominującego, lecz zmiana dominującej cywilizacji (Sulmicki, 2015).

Gospodarka Chin jest obecnie największą pod względem bezwzględnej wartości produktu krajowego brutto (PKB) liczonego parytetem siły nabywczej. Globalny udział w produkcji przemysłowej Chin w latach 1980-2010 zwiększył się z około 4\% do 19,8\%. W 2013 roku Państwo Środka uzyskało największą wartość obrotów handlowych na świecie (Oziewicz, 2015). Jednak zdobycie pozycji dominującej, jeśli do tego dojdzie, zajmie ChRL kilka najbliższych dziesięcioleci. W połowie XXI wieku państwa azjatyckie mogą wypracowywać nawet połowę światowego PKB.

Niewątpliwie jednym z najważniejszych czynników, który będzie w kolejnych dekadach kształtował światowy ład gospodarczy, jest rozwój chińskiej gospodarki. Dopatrując się w Państwie Środka roli globalnego lidera, należy pamiętać o uwarunkowaniach, procesach i problemach, które przechodziło i z którymi zmaga się obecnie największe pod względem liczby ludności państwo świata. Podstawami dynamicznego wzrostu gospodarczego Chin były ogromne inwestycje i strategia maksymalizacji eksportu. Rozwój oparty był głównie na pracochłonnych i energochłonnych sektorach przemysłu (Liberska, 2010). Ponadto, z powodu zacofania technologicznego i braku własnego kapitału, dużą rolę odgrywały inwestycje zagraniczne przedsiębiorstw pochodzących z krajów zachodnich. Dzięki dostarczeniu kapitału i technologii produkcji uzyskały one dostęp do ogromnej liczby tanich pracowników, co pozwoliło na generowanie wysokich zysków z zainwestowanych środków.

W efekcie wyżej wymienionych procesów chińska gospodarka z roku na rok notowała imponujący wzrost gospodarczy. Oparcie rozwoju na zagranicznym kapitale w dłuższej perspektywie przyniosło jednak również negatywne skutki. Obecnie prawie połowa eksportowanych z Chin produktów i trzy czwarte zaawansowanych technologicznie towarów produkowana jest przez zagraniczne przedsiębiorstwa. Ponadto ChRL znajduje się w dużej mierze na końcu globalnego łańcucha produkcji, co oznacza, że następuje tam ostateczne „składanie” gotowych produktów z komponentów produkowanych w innych krajach. Pozornie Chiny eksportują wiele zaawansowanych 
technologicznie produktów, jednakże, przyglądając się bliżej strukturze własności i łańcuchowi produkcji, zauważamy, że nie może to być świadectwem wysokiego stopnia zaawansowania chińskich firm. Do około 2006 roku gospodarka ChRL oparta była głównie na kapitale zagranicznym, od tego czasu podejmowane są próby jej uniezależniania (Kroeber, 2016).

Innym istotnym czynnikiem kształtującym w ostatnich latach sytuację ekonomiczną Chin jest model rozwoju oparty w dużej mierze na inwestycjach infrastrukturalnych. W ciągu ostatnich trzech dekad dokonano ogromnych inwestycji mających na celu stworzenie podstaw kraju rozwiniętego. W początkowej fazie reform zdecydowana większość ludzi zamieszkiwała wsie i zajmowała się mało dochodowym rolnictwem. Aby wykorzystać potencjał ludzki, konieczne było stworzenie przedsiębiorstw przemysłowych, pozyskanie technologii produkcji i sposobów zarządzania, budowa wewnętrznej sieci komunikacyjnej i transportowej. Należało również ustanowić połączenia z globalnym rynkiem, eksport towarów wymagał budowy portów i lotnisk.

Inwestycje infrastrukturalne były ogromne, jednak współcześnie konieczna jest zmiana modelu rozwojowego. Kolejnym krokiem musi być zwiększenie efektywności gospodarki opartej na zgromadzonym do tej pory kapitale. W tym aspekcie największe trudności pojawiają się przy próbach poprawy efektywności działalności ogromnych przedsiębiorstw państwowych powstałych w okresie industrializacji. Są one zdecydowanie mniej produktywne od firm prywatnych, a dysponują większością środków ze względu na autorytarny system polityczny (Kroeber, 2016). Głównymi założeniami nowego modelu rozwojowego są więc: zwiększenie efektywności produkcji, zwiększenie konsumpcji wewnętrznej, stopniowe uniezależnianie się od kapitału zagranicznego oraz próba zmniejszenia negatywnego oddziaływania przemysłu na stan środowiska naturalnego.

Jednym z konkretnych działań podjętych przez władze chińskie w celu zwiększenia efektywności gospodarki jest projekt Made in China 2025. Obejmuje on szereg programów dążących do podniesienia jakości i poziomu technologicznego rodzimych firm. Swoim zasięgiem ma objąć procesy produkcyjne oraz zawiązane z nimi usługi (Kroeber, 2016). Szczególna uwaga ma być poświęcona dziesięciu strategicznym sektorom gospodarki:

- zaawansowanym technologiom informatycznym,

- automatyce i robotyce,

- lotnictwu i urządzeniom obsługującym ruch powietrzny,

- zaawansowanym urządzeniom obsługującym transport morski,

- transportowi kolejowemu,

- pojazdom i urządzeniom elektrycznym,

- urządzeniom do produkcji energii,

- sprzętowi rolniczemu,

- nowym materiałom,

- medycynie i biotechnologii (Kennedy, 2015).

Jednym ze sposobów pozyskiwania zaawansowanych technologii są przejęcia zagranicznych firm, mających swoje siedziby w wysoko rozwiniętych krajach zachodnich. Jest to jeden z głównych motywów podejmowanego od kilku lat, systematycznie zwiększającego swój zasięg i natężenie, procesu ekspansji zagranicznej chińskich przedsiębiorstw. 


\section{CHIŃSKIE INWESTYCJE ZAGRANICZNE}

Bardzo znaczącym przejawem globalnej ekspansji chińskich przedsiębiorstw są inwestycje zagraniczne. Mają one służyć przede wszystkim wzmocnieniu chińskiej potęgi gospodarczej, jako że politykę zagraniczną ChRL cechuje kierowanie się głównie interesami ekonomicznymi (Shambaugh, 2013). Proces zagranicznej aktywności podmiotów pochodzących z Państwa Środka rozpoczął się w 2001 roku, wraz ogłoszeniem strategii going out, zachęcającej i wspomagającej działalność chińskich firm za granicą. Od około 2005 roku obserwujemy coraz bardziej znaczące wartości chińskich bezpośrednich inwestycji zagranicznych (BIZ). Najbardziej dynamiczny wzrost odpływu kapitału pieniężnego notujemy od 2014 roku (ryc. 1). W 2015 roku wartość chińskich BIZ zbliżyła się do wartości inwestycji zagranicznych lokowanych w Chinach. Dokonuje się zatem bardzo istotna zmiana. Chiny były dotychczas kojarzone głównie jako biorca zagranicznego kapitału pieniężnego, niezbędnego do szybkiego rozwoju gospodarczego, dokonującego się w ciągu ostatnich prawie 40 lat. Można spodziewać się, że w najbliższym czasie wartość chińskich inwestycji zagranicznych będzie przewyższała wartość BIZ napływających do ChRL. Już obecnie Chiny są trzecim, po Stanach Zjednoczonych i Japonii, eksporterem inwestycji zagranicznych (UNCTAD, 2016).

Ryc. 1. Wartość napływu i odpływu BIZ z i do Chin w latach 2005-2016

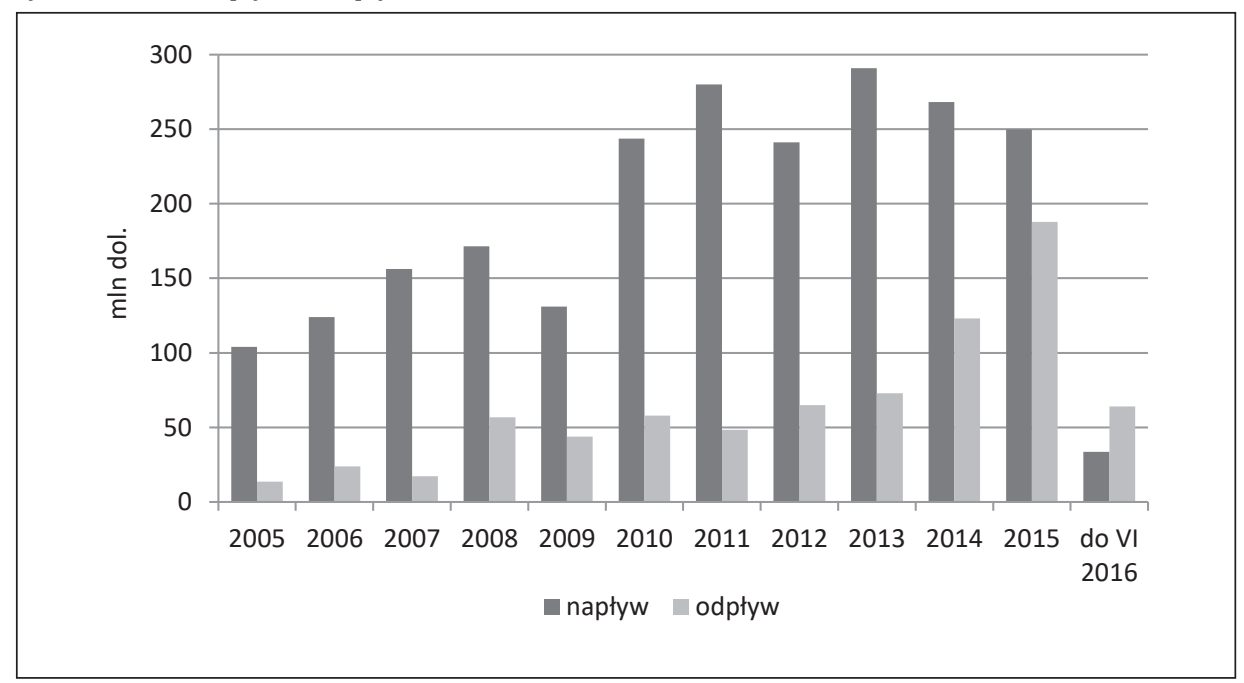

Źródło: opracowanie własne na podstawie danych OECD (2016, 31 grudnia)

\section{PRZEJĘCIA EUROPEJSKICH PRZEDSIĘBIORSTW PRZEZ CHIŃSKICH INWESTORÓW}

W pierwszych latach zagranicznej działalności inwestycyjnej transfer kapitału z ChRL miał przede wszystkim na celu zapewnienie dostaw surowców. Rozwój gospodarczy Państwa Środka był wówczas oparty na ogromnych inwestycjach infrastrukturalnych, konieczne więc było dostarczanie coraz większych ilości surowców. Do około 2012 roku dominowały transakcje przeprowadzane w słabiej rozwiniętych krajach, posiadających bogate złoża. Chińska ekspansja dokonywała się więc głównie na terenie Azji, 
Ryc. 2. Liczba i wartość największych chińskich przejęć firm europejskich

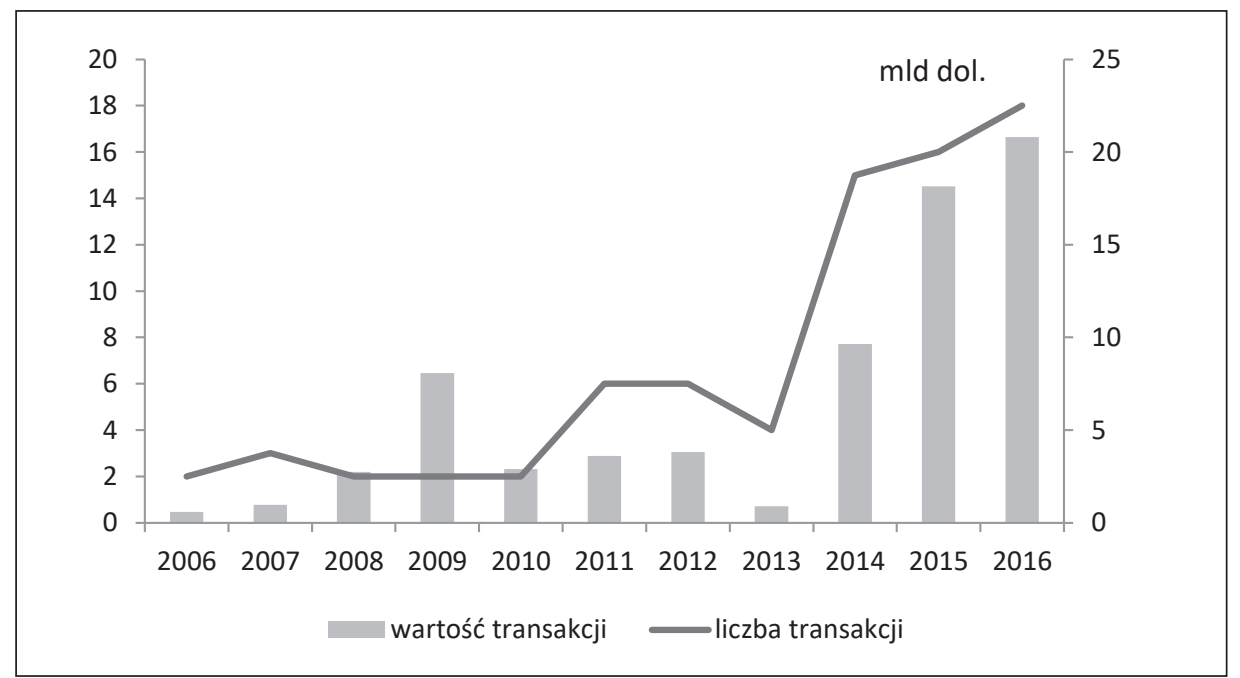

Źródło: opracowanie własne na podstawie danych AEI (2016, 31 grudnia)

część środków była inwestowana również w Afryce i Ameryce Południowej (Casaburi, 2016). Głównym celem tych działań była dywersyfikacja dostaw surowców oraz utrzymanie bezpieczeństwa energetycznego.

Jednakże wraz ze zmianą modelu rozwojowego, w ostatnich dwóch-trzech latach nastąpił zdecydowany wzrost wartości kapitału pieniężnego eksportowanego do krajów europejskich oraz do Stanów Zjednoczonych. Ogromne rezerwy walutowe Chin oraz kryzys dotykający wiele przedsiębiorstw z krajów zachodnich stwarzają możliwości przepływu kapitału w odwrotnym kierunku niż ten, który obserwowaliśmy w ciągu ostatnich 30-40 lat.

Przedmiotem niniejszej pracy są najbardziej znaczące przejęcia europejskich przedsiębiorstw dokonane $\mathrm{w}$ latach 2006-2016. Pomimo tego że zgromadzone dane dotyczą niewielkiej liczby transakcji, można zauważyć, że ich wartość oraz liczba transakcji wykazują podobną tendencję do kształtowania się ogólnego odpływu kapitału pieniężnego z Państwa Środka (ryc. 1, ryc. 2). Od 2014 roku następuje zdecydowane zwiększanie się wartości i liczby przejęć europejskich podmiotów gospodarczych przez chińskie firmy. Pod względem wartości poszczególnych transakcji można wyróżnić trzy przejęcia o znacznie wyższej wartości niż pozostałe.

Pierwszym była akwizycja w 2009 roku szwajcarskiej firmy Addax Petroleum przez Sinopec. W tym okresie wśród chińskich inwestycji dominowały te mające na celu pozyskanie surowców energetycznych. Sinopec, państwowy gigant zajmujący się wydobyciem, przetwarzaniem oraz dystrybucją ropy naftowej i gazu ziemnego, zyskał dzięki tej transakcji dostęp do złóż ropy naftowej w kurdyjskim regionie autonomicznym, będącym częścią Iraku, oraz złóż znajdujących się w zachodniej Afryce (Koszek, 2014).

Nieco wyższą wartością odznaczał się zakup znanego włoskiego producenta opon Pirelli za kwotę 7,5 mld dol. przez ChemChina.

Największym przejęciem w badanym okresie była jednak akwizycja twórcy gier na urządzenia mobilne, fińskiej firmy Supercell, o wartości przekraczającej 8 mld dol., przez Tencent. Wartość tych transakcji może zostać w najbliższym czasie wielokrotnie 
przewyższona, jeśli dojdzie do będącego w zaawansowanym stadium przejęcia szwajcarskiego przedsiębiorstwa Syngenta przez ChemChina. Operacja ma być przeprowadzona za kwotę około $44 \mathrm{mld}$ dol. Wyżej wymienione największe dotychczasowe akwizycje dobrze obrazują rozwój badanego w niniejszej pracy procesu. Po początkowym skupieniu się na pozyskiwaniu surowców energetycznych następuje reorientacja chińskich inwestycji w kierunku zdobywania technologii produkcji dla rodzimych firm oraz uznanych marek, w celu podniesienia wizerunku chińskich przedsiębiorstw oraz produkowanych przez nie towarów (por. tab. 1).

Wraz ze wzrostem liczby i wartości chińskich inwestycji w Europie rośnie również zróżnicowanie sektorowe przejmowanych przedsiębiorstw. Do 2013 roku były to głównie przejęcia firm związanych z przetwórstwem przemysłowym, natomiast od 2014 roku obserwujemy wyraźną dywersyfikację sektorową (ryc. 3). Poszerzanie się zakresu działalności przejmowanych podmiotów może świadczyć o dużym potencjale chińskich inwestorów oraz wskazywać na możliwe zwiększanie się napływu chińskiego kapitału pieniężnego w kolejnych latach.

Rozpatrując rozmieszczenie przejętych przedsiębiorstw można zauważyć, że skupiają się one w wysoko rozwiniętych krajach Europy Środkowej, takich jak Niemcy, Holandia, Belgia, Szwajcaria, oraz na północy Włoch. W Wielkiej Brytanii odnotowano

Ryc. 3. Zróżnicowanie działalności firm przejętych przez chińskich inwestorów

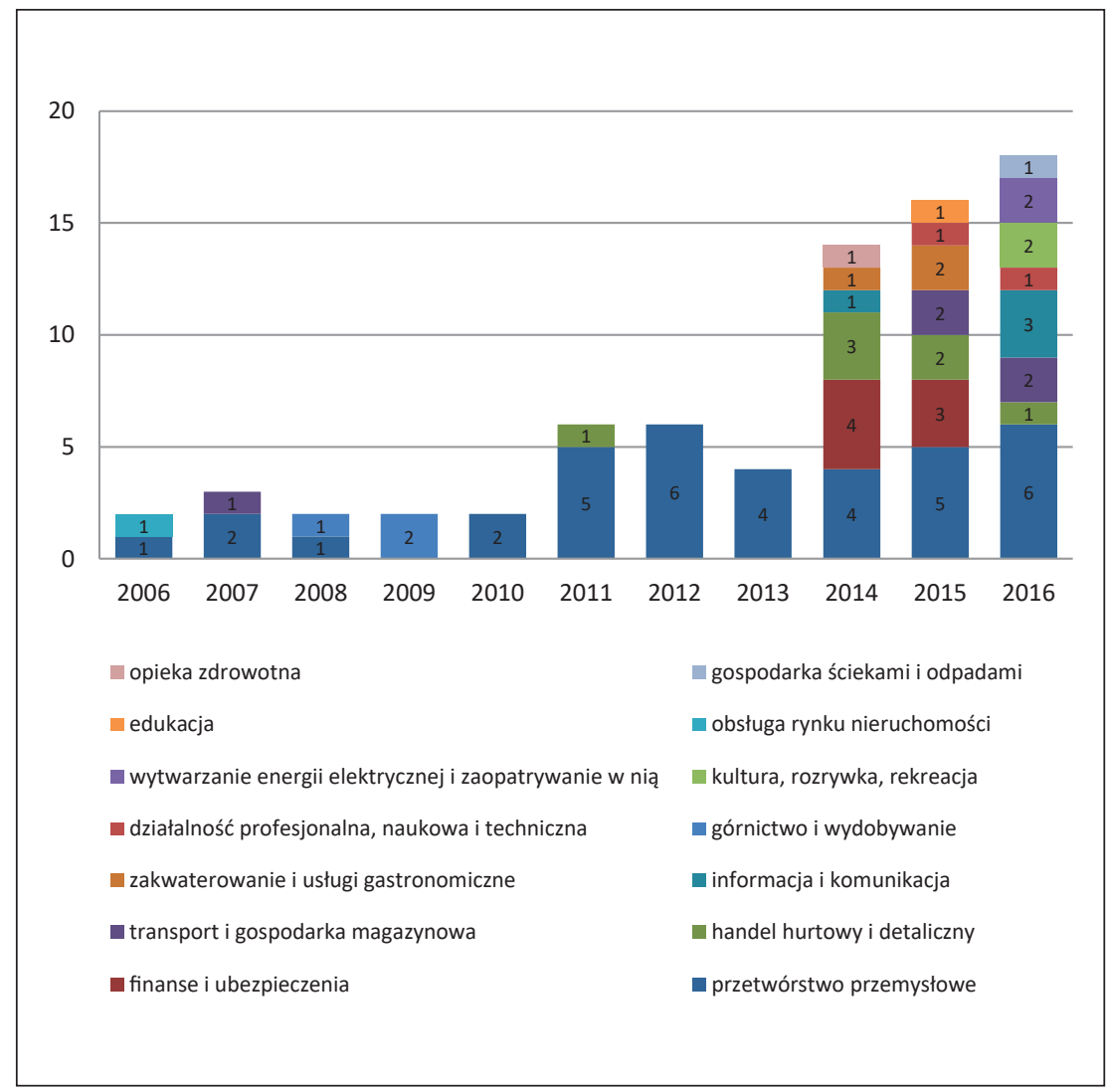

Źródło: opracowanie własne na podstawie danych AEI (2016, 31 grudnia) 
Ryc. 4. Rozmieszczenie największych przejęć europejskich firm przez chińskich inwestorów

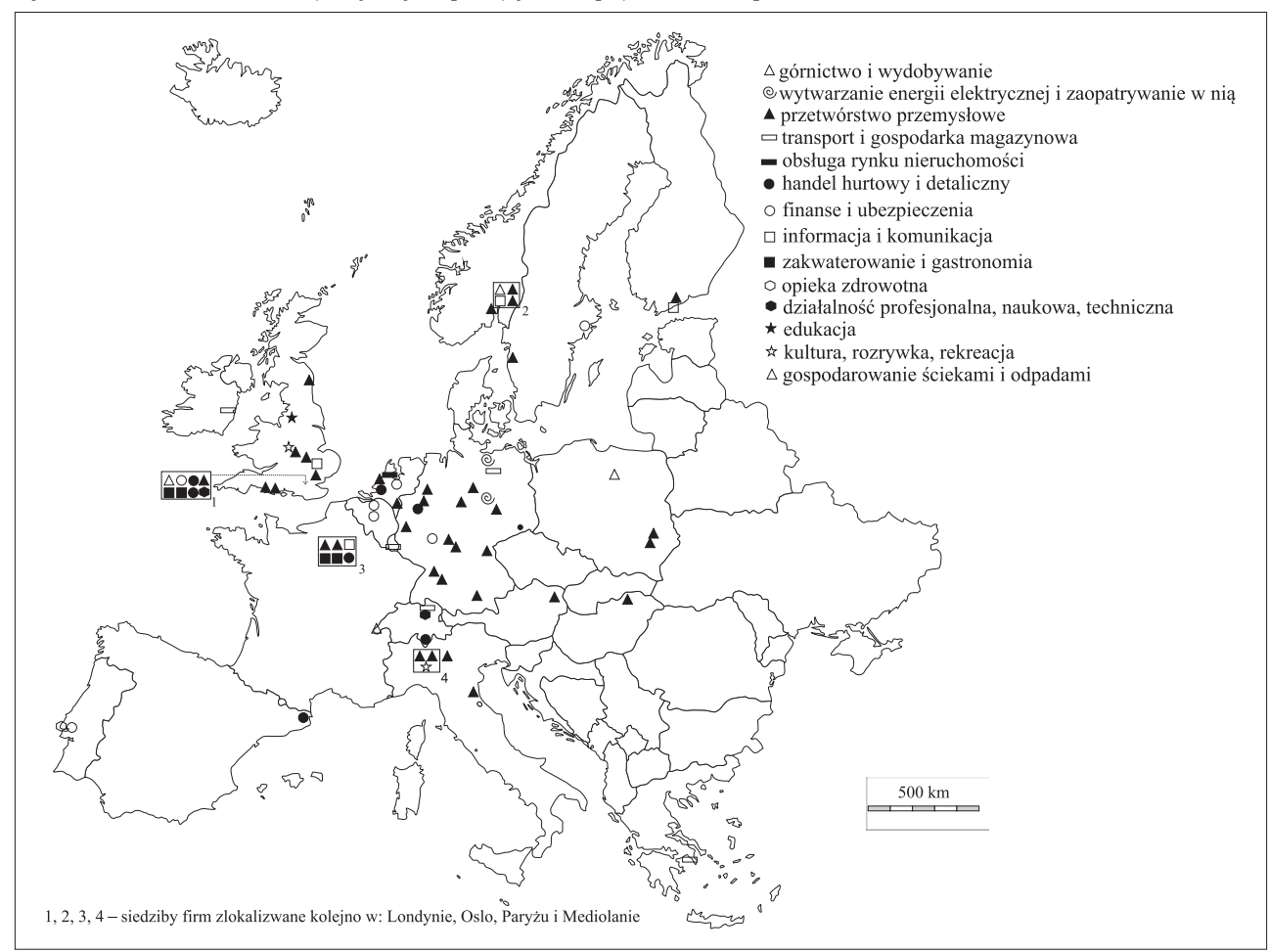

Źródło: opracowanie własne na podstawie danych AEI (2016, 31 grudnia)

17 przejęć i była to największa liczba inwestycji. Taką samą liczbę akwizycji chińskie firmy dokonały w Niemczech. Inną cechą rozmieszczenia badanych transkacji jest fakt, iż w wielu przypadkach koncentrują się one w obrębie największych metropolii, będących stolicami poszczególnych krajów. Zjawisko takie możemy zaobserwować w Londynie, Paryżu, Lizbonie czy Oslo. Może to być oznaką początkowego charakteru działań Chińczyków, dla których największe miasta są najłatwiej osiągalne i dotychczas najlepiej poznane. Na tym tle wyróżniają się inwestycje w Niemczech, ulokowane w różnych częściach kraju.

Należy pamiętać, że chińskie przedsiębiorstwa są nowymi graczami na rynku międzynarodowych inwestycji, zmuszone są więc działać często w warunkach dużej niepewności, ograniczonej wiedzy oraz dużego ryzyka, szczególnie w odległych krajach europejskich, cechujących się odmienną specyfiką uwarunkowań prawnych, instytucjonalnych i kulturowych (Dollar, 2015).

\section{PoDSUMOWANIE}

Jednym z najważniejszych czynników wpływających współcześnie na globalny ład gospodarczy jest rozwój ekonomiczny ChRL. W ostatnich latach obserwujemy coraz bardziej intensywną ekspansję kapitałową przedsiębiorstw pochodzących z Państwa Środka. Przejawem tego procesu są akwizycje europejskich przedsiębiorstw, których wartość i liczba wzrasta z roku na rok. 
Głównym celem chińskich inwestycji w Europie jest uzyskanie dostępu do technologii produkcji, które są w posiadaniu zaawansowanych firm Starego Kontynentu. Jest to konieczne w związku z reformami prowadzonymi obecnie przez władze chińskie. Ważnym motywem podejmowanych przejęć jest również chęć pozyskania renomowanych marek, w celu polepszenia wizerunku wytwarzanych w Chinach produktów.

Wraz ze wzrostem wartości i liczby przejęć europejskich podmiotów gospodarczych można zaobserwować dywersyfikację sektorową prowadzonych działań. Może to być oznaką pozytywnego trendu i wskazywać na duży potencjał chińskich inwestorów. Pomimo tego, że przedsiębiorstwa pochodzące z Państwa Środka są nowymi graczami na europejskim rynku inwestycji zagranicznych, dla wielu pogrążonych w kryzysie firm z krajów zachodnich są ważnym źródłem kapitału niezbędnego do dalszego funkcjonowania, a w przyszłości ich znaczenie może stać się jeszcze większe.

Proces przejmowania kontroli nad znaczącymi europejskimi przedsiębiorstwami przyniesie zapewne nowe, dotychczas nieznane i trudne do przewidzenia konsekwencje.

\section{Literatura \\ References}

AEI (2016, 31 grudnia). Dane statystyczne udostępniane przez American Enterprise Institute. Pozyskano z http://www.aei.org/

Casaburi, I. (2016, 10 października). Chinese Investment in Europe 2015-16. ESADE China Europe Club. Pozyskano z: http://www.esadegeo.com/

Clegg, J., Voss, H. (2016). The new two-way street of Chinese direct investment in the European Union. China-EU Law Journal, 5, 79-100. Doi:10.1007/s12689-016-0063-x

Dollar, D. (2015, 15 sierpnia). China's rise as a regional and global power: The AIIB and the 'one belt, one road'. Horizons. Pozyskano z https://www.brookings.edu/research/chinas-rise-as-a-regional-and-global-power-the-aiib-and-the-one-belt-one-road/

Dreger, C., Schüler-Zhou, Y., Schüller, M. (2016). Determinants of Chinese Direct Investments in the European Union. DIW Berlin Discussion Paper, 1480, 1-19.

Hanemann, T., Huotari, M. (2015) (2016, 15 listopada). A New Record Year for Chinese Outbound Investment in Europe. The Mercator Institute for China Studies. Pozyskano z https://www. merics.org/en/press-contact/press-releases/a-new-record-year-for-chinese-outbound-investment-in-europe/

Kennedy, S. (2015, 1 czerwca). Made in China 2025. Center for Strategic and International Studies. Pozyskano z https://www.csis.org/analysis/made-china-2025

Koszek, R. (2014). Chińskie inwestycje w Europie w czasie światowego kryzysu gospodarczego. Prace Studenckiego Koła Naukowego Geografów Uniwersytetu Pedagogicznego w Krakowie, $3,46-62$.

Kroeber, A.R. (2016). China's Economy: What Everyone Needs to Know? Nowy Jork: Oxford University Press.

Liberska, B. (2010). Perspektywy rozwojowe chińskiej gospodarki do 2050 roku. Studia Ekonomiczne, 4, 331-358.

OECD (2016, 31 grudnia). Dane statystyczne Organizacji Współpracy Gospodarczej i Rozwoju. Pozyskano z http://www.oecd.org/

Oziewicz, E. (2015). Rola Chin we współczesnej globalnej gospodarce. Gdańskie Studia Azji Wschodniej, 8, 142-151.

Shambaugh, D. (2013). China Goes Global: The Partial Power. Nowy Jork: Oxford University Press. Sulmicki, J. (2015). Chiny umacniają dominującą pozycję w gospodarce światowej. Zeszyty Naukowe Uczelni Vistula, 41(3), 33-44. 
Szunomar, A. (2016, 7 grudnia). The characteristics, changing patterns and motivations of Chinese investment in Europe. Friends of Europe. Pozyskano z: http://www.friendsofeurope.org/ global-europe/the-characteristics-changing-patterns-and-motivations-of-chinese-investment-in-europe/

UNCTAD (2016). World Investment Report. Genewa: United Nations.

Rafał Koszek, mgr, doktorant, Uniwersytet Pedagogiczny w Krakowie, Instytut Geografii. Zainteresowania badawcze autora koncentrują się wokół trzech głównych zagadnień: rozwoju chińskiej gospodarki i jej wpływu na inne regiony świata, szczególnie na państwa europejskie; historii i współczesnego rozwoju Drogi św. Jakuba, geografii finansów. W roku akademickim 2014/2015 nagrodzony Stypendium Ministra Nauki i Szkolnictwa Wyższego za wybitne osiągnięcia naukowe.

Rafał Koszek, M.Sc., Ph.D. candidate, Pedagogical University of Cracow, Institute of Geography. Author's research interests concern three main fields: Chinese economic growth and its influence on other regions, especially on the European countries; history and contemporary development of the St. James Way; financial geography. In the academic year 2014/2015 awarded with the Fellowship of Ministry of Science and Higher Education for outstanding academic achievements.

\section{Adres/address:}

Uniwersytet Pedagogiczny w Krakowie

Instytut Geografii

ul. Podchorążych 2, 30-084 Kraków, Polska

e-mail: rkoszek@gmail.com 